\title{
Current Development and Research Trend of Chemotherapeutic Agents for Head and Neck Squamous Cell Carcinoma
}

\author{
Yoon Se Lee ${ }^{\mathbb{D}}$ \\ Department of Otolaryngology, Asan Medical Center, University of Ulsan College of Medicine, Seoul, Korea
}

\section{두경부 편평상피세포암에 대한 최근 약제 개발과 연구 방향}

\author{
이 윤 세 \\ 울산대학교 의과대학 서울아산병원 이비인후과학교실
}

\author{
Received June 17, 2019 \\ Revised August 15, 2019 \\ Accepted August 28, 2019 \\ Address for correspondence \\ Yoon Se Lee, MD, PhD \\ Department of Otolaryngology, \\ Asan Medical Center, \\ University of Ulsan \\ College of Medicine \\ 88 Olympic-ro 43-gil, Songpa-gu, \\ Seoul 05505, Korea \\ Tel +82-2-3010-3710 \\ Fax +82-2-489-2773 \\ E-mail manseilee@gmail.com
}

\begin{abstract}
After FDA approval of cetuximab at 2006, receptor tyrosine kinase, including an epidermal growth factor receptor, blocking agents have been evaluated for head and neck squamous cell carcinoma (HNSCC). Agents targeting PI3K/Akt/mTOR, IL-6/JAK/STAT3, vascular endothelial growth factor receptor, and cyclin D-CDK-4/6-INK4/Rb pathway have developed. Most of them have failed to demonstrate better treatment outcome in recurrent and/or metastatic $(R / M)$ HNSCC than conventional chemotherapy. Since a pivotal role of PD-1/PD-L1 pathway in immunological tumor microenvironment was revealed, the immune checkpoint inhibitors, including pembrolizumab and nivolumab, have opened new paradigm of cancer treatment modality and propagates other immune-based therapies for R/M HNSCC. Various types of combination trials consisting of immunotherapy with other class of immunotherapy, targeted agents, radiation therapy, or conventional chemotherapy have been under investigation to improve treatment outcome. Biomarker studies to find an optimal candidate for the newly developed agents are accompanied. These clinical trials lead to tailored approach based on immunotherapy with precision medicine is expected to lead to promising results.
\end{abstract}

Korean J Otorhinolaryngol-Head Neck Surg 2019;62(9):487-98

Key Words Chemotherapy - Head and neck squamous cell carcinoma ·

Human papillomavirus - Immunotherapy $\cdot$ Molecular targeted therapy.

\section{서 론}

전세계적으로 두경부암은 악성종양 중 6번째로 흔하며 암 과 관련된 사망 원인 중 $2 \%$ 를 차지할 정도로 비중이 높다. ${ }^{1)}$ 두경부편평상피세포암(head and neck squamous cell carcinoma, HNSCC)의 전통적인 원인으로 흡연과 음주가 있으 며 최근에는 인체 유두종바이러스(human papillomavirus,

This is an Open Access article distributed under the terms of the Creative Commons Attribution Non-Commercial License (https://creativecommons.org/licenses/by-nc/4.0) which permits unrestricted non-commercial use, distribution, and reproduction in any medium, provided the original work is properly cited.
$\mathrm{HPV}$ )가 유발하는 구인두암의 비중이 증가하고 있다. ${ }^{2)} \mathrm{HPV}$ (+) 구인두암의 분자생물학적, 임상적 특징이 HPV(-) HNSCC 와는 다르다는 연구 결과를 반영하여 전통적인 tumor-nodemetastasis(TNM) 병기시스템이 American Joint Committee on Cancer(AJCC) staging system 8판부터 변경되었다. 이러 한 변화 뿐만 아니라 최근에는 HNSCC에 대한 돌연변이와 표현형의 유전체를 연구한 The Cancer Genome Atlas(TCGA) 자료를 통해서 HNSCC의 유전체의 특징을 분석하였다. ${ }^{3)} 2011$ 년에는 Notch1 돌연변이가 HNSCC에서 예상과 달리 많이 분포하고 있음을 발견하였고 ${ }^{4,5)}$ 2015년에는 TCGA consor- 
tium이 279 개의 원발암에 대한 유전체 분석을 보고하였다.) 최근의 오믹스와 같은 정밀의학(precision medicine)의 발전 으로 인해 종양에 대한 copy number alterations, 유전자와 단백질 발현 형태와 후성적(epigenetic) 변형에 대한 연구가 가능해졌다. 이러한 연구를 바탕으로 새로운 치료 타겟이 될 수 있는 유전자와 단백질을 찾는 표적 치료에 대한 기대감이 상승되었다.

상당수의 환자가 진행된 병기에서 발견되어 공격적이고 다 양한 치료를 시행하더라도 재발하거나 원격전이가 발생할 확률은 $30 \%$ 에 이른다. ${ }^{1.7)}$ 주로 사용되고 있는 platinum 기반 의 치료에 저항성을 보이는 환자의 예상 수명은 1 년 미만이 다. ${ }^{8}$ 전통적인 항암 치료와 동시항암 방사선 치료는 HNSCC 환자의 생존율을 획기적으로 개선시키지 못하고 있다.,10) 그 렇기 때문에 재발 또는 전이암(recurrent or metastatic $\mathrm{HN}^{-}$ $\mathrm{SCC}, \mathrm{R} / \mathrm{M} \mathrm{HNSCC}$ )에 대한 새로운 치료 약제의 개발이 중요 하다. 게다가 기존의 항암제는 심각한 부작용을 유발할 수 있 기 때문에 표적 치료를 통해 부작용을 줄이면서 치료 효과를 개선할 수 있는 방법을 개발하고자 하였다. 대표적인 예로 2006년에 FDA의 승인을 받은 epidermal growth factor receptor(EGFR) inhibitor인 cetuximab이 있다. EGFR은 transmembrane tyrosine kinase 수용체로 Ras, PI3K와 같은 내 부 신호체계를 활성화시켜서 세포의 분열, 혈관 형성, 침습, 전 이를 일으키는 데 기여한다. ${ }^{11)}$ 그렇기 때문에 platinum 치료에 대해 저항성을 보이는 HNSCC에 대해서 cetuximab을 사용 할 경우 치료 성적이 개선된 것으로 알려져 있으나 cetuximab 치료에 대한 저항성을 보이는 경우도 많고 적합한 환자를 찾 아내기 위한 표지자를 발견하지는 못하였다. ${ }^{12)}$ 그러므로 아직 까지 국소적으로 진행된 $\mathrm{HNSCC}$ 에 사용되는 CCRT에는 cisplatin이 1차 약제로 고려되고 있으며, ${ }^{13)}$ cetuximab의 경우 $\mathrm{HPV}(+)$ 구인두암에서 방사선과 병용해서 사용한다면 cisplatin과 방사선 치료 병합요법에 비해서 약간의 생존율 개선 효과를 보인다. ${ }^{14)}$ 유전자 변이에 대한 표적 치료가 가시적인 성 과를 보이지 못하고 있는 사이에, 최근에는 종양 면역학이 발 전하면서 종양세포와 그 주위의 면역세포를 이용한 치료법이 각광을 받기 시작하였다. ${ }^{15)}$ 전통적인 항암제와 cetuximab, afatinib 이외에 면역관문 억제제(immune checkpoint inhibitor)가 재발 또는 전이성(recurrent or metastatic, R/M) HNSCC 에 대한 2 차 약제로 인정을 받기 시작하였다. 이번에는 세포 내 신호기전을 표적으로 하는 표적 치료제의 개발 현황과 면 역치료제의 적용 범위의 확대와 앞으로의 연구방향에 대해 설명하고자 한다.

\section{본 론}

\section{세포 신호기전 표적 치료제}

EGFR, ErbB, PI3K/Akt/mTOR, IL-6/JAK/STAT3, cyclin $\mathrm{D}-\mathrm{CDK} 4 / 6-\mathrm{Rb}$ 신호기전이 최근까지 HNSCC에 대한 치 료 표적으로 사용되었다. $\mathrm{HNSCC}$ 에 대해서 최근까지 연구되 고 있는 신호기전에 따른 약제를 정리하였다(Table 1, Fig. 1).

\section{EGFR targeting drugs}

EGFR을 통한 신호는 암세포의 생존과 분열, 혈관증식과 전이를 촉진시킨다. ${ }^{16)} \mathrm{EGFR}$ 은 $\mathrm{HNSCC}$ 의 50 90\%에서 발현 되며 발현 정도가 높을 경우에 나쁜 예후, 방사선 치료에 대 한 반응성 저하, 높은 재발율과 연관되어 있다. ${ }^{17)} \mathrm{EGFR}$ 에 대 한 표적치료제는 단일클론 항체(monoclonal antibody)인 cetuximab, panitumumab와 tyrosine kinase inhibitor(TKI) 인 gefitinib, erlotinib, afatinib, lapatinib로 분류할 수 있다. 단일클론 항체의 경우 수용체의 외부에 결합하여 수용체가 활성화가 되지 않고 억제되는 것을 유발한다. ${ }^{18)} \mathrm{TKI}$ 는 수용체 내부의 ATP 결합 부위를 억제하여 tyrosine kinase의 활성 도를 억제한다. 국소적으로 진행한 HNSCC에 대해서 방사선 치료를 단독으로 사용하는 것보다 cetuximab과 방사선 치료 를 같이 사용할 경우 전반적인 생존율(overall survival, OS)

Table 1. Molecular targets and matched agents currently available for head and neck squamous cell carcinoma

\begin{tabular}{ll}
\hline Mechanism of action & \multicolumn{1}{c}{ Drugs } \\
\hline EGFR inhibitor & Cetuximab \\
ErbB family inhibitor & Afatinib \\
PI3K inhibitor & Buparlisib (BKM-120) \\
& Alpelisib (BYL-719) \\
& Copenlisib \\
& Taselisib \\
mTOR inhibitor & Everolimus \\
& Temsirolimus \\
JAK1/2 inhibitor & Dactolisib (combined with PI3K-inhibition) \\
STAT3 inhibitor & AZD9150 \\
Angiogenesis & C188-9 \\
inhibitor & Bevacizumab \\
& Pazopanib \\
CDK 4/6 inhibitor & Axitinib \\
& Palbociclib \\
HGF inhibitor & Ribociclib \\
& Abemaciclib \\
& Ficlatuzumab (AV-299)
\end{tabular}

EGFR: epidermal growth factor receptor, mTOR: mammalian target of rapamycin, CDK: cyclin dependent kinase 


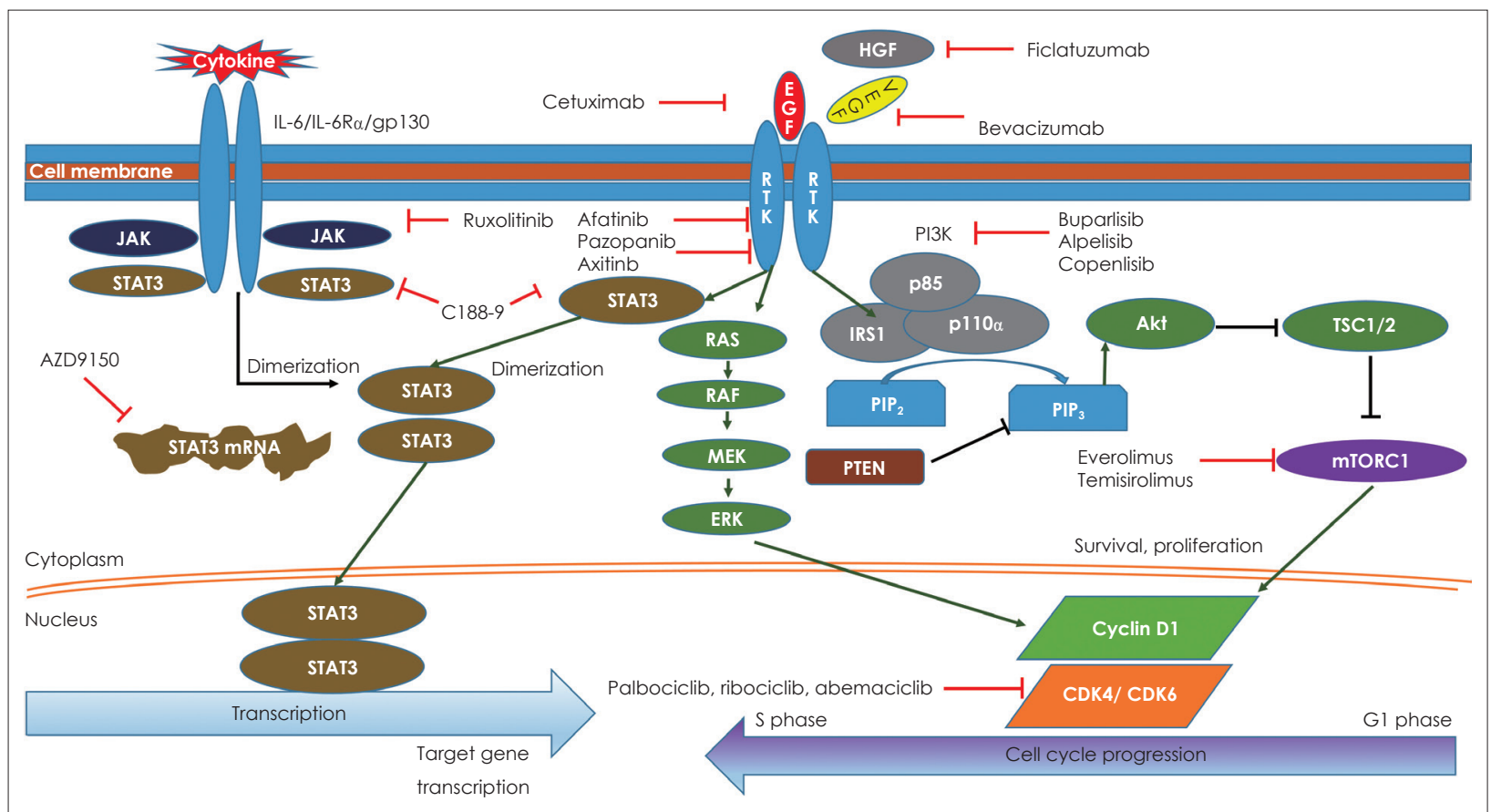

Fig. 1. Receptor tyrosine kinase and cytokine-related signaling pathways in head and neck squamous cell carcinoma. Adapted from Lee YS, et al. Expert Opin Emerg Drugs 2018;23(4):283-99.15)

이 20개월 가량 증가하였다. ${ }^{12)}$ 이후 연구에서 병합 치료(45.6\%) 의 5년 생존율이 방사선 단독 치료(36.4\%)보다 우수하였으며 이를 바탕으로 2006년 국소진행 HNSCC에 대해서 FDA 승 인을 받았고 cetuximab의 적응증이 R/M HNSCC까지 확대 되었다. ${ }^{19)}$ Eastern Cooperative Oncology Group에 의해 시행 되어진 R/M HNSCC에 대한 연구에서 cetuximab+cisplatin 환자들의 반응율이 $(26 \%)$ cisplatin 단독인 환자들(10\%)보다 개선되었다. ${ }^{20)}$ Progression-free survival(PFS)과 OS 또한 개 선되었지만 통계학적인 유의성은 없었다. Cisplatin에 대한 반 응이 없던 환자들을 대상으로 한 연구에서는 질병조정율[disease control ratel(DCR); partial remission, complete remission, and stable disease]이 46\%였다. ${ }^{21)} 5-\mathrm{FU} /$ platinum 기반 항암 치료에 cetuximab을 추가할 경우 OS와 PFS가 각각 7.4 개월에서 10.1 개월, 3.3 개월에서 5.6 개월로 개선되는 것을 확인 하였다. ${ }^{22)}$ 이러한 연구를 바탕으로 FDA와 European Medicine Agency(EMA)에서 2011년에 R/M HNSCC에 대한 치 료로 cetuximab의 추가 사용을 허가하였다. Panitumumab 은 EGFR을 억제하는 $\mathrm{IgG} 2$ 항체이다. R/M HNSCC에 대한 3상 연구에서 panitumumab을 병용할 경우 PFS는 1.2개월 정도 개선되는 효과를 보였으나 통계학적인 의미를 찾을 수 는 없었다. ${ }^{23)}$ 대신에 3단계 이상의 설사, 부정맥, 저마그네슘혈 증, 안독성이 panitumumab을 사용한 환자군에서 자주 발생 하였기 때문에 HNSCC에 대한 치료 약제로 현재 사용되고 있 지 않다.
EGFR은 EGFR/ErbB1/human epidermal growth factor receptor(HER)-1, ErbB2/HER-2/neu, ErbB3/HER-3, ErbB4/ HER-4를 포함하는 ErbB군에 속하는 수용체이다. ${ }^{24}$ 수용체 내부의 신호기전을 억제하기 위해서 TKI가 여러 임상 시험에 서 사용되었으며 afatinib, dacomitinib, gefitinib, erlotinib, lapatinib, vandetanib이 최근에 사용되었다. Afatinib은 비가 역적으로 EGFR, ErbB2/HER-2, ErbB4/HER-4를 억제하 며 R/M HNSCC에 대한 임상 시험이 주를 이루었다. National Comprehensive Cancer Network(NCCN) guideline에서 $\mathrm{R} / \mathrm{M}$ HNSCC에 대해서 2차 약제로 권장하고 있다. Afatinib 을 투여받은 환자는 methotrexate를 투여받은 환자들보다 $\operatorname{PFS}(2.6$ 개월), ORR(10\%)이 개선되었다. 구인두암이 아니고 p16(-), 높은 phosphatase tensin homolog(PTEN) 발현, 낮 은 HER-3 발현, 높은 EGFR이 좋은 치료 반응을 예측하는 인자였다. ${ }^{25)}$ Afatinib의 효과를 cetuximab과 비교하였을 때 비슷한 ORR, DCR을 보였지만 약제 관련 부작용은 afatinib 투여군에서 더 높았다. ${ }^{26)}$ 치료에 대한 반응이 없었던 경우에 두 가지 약제를 교차 사용을 하여도 저항성을 보이는 경우가 없었다. 국소적으로 진행되고 절제가 불가한 $\mathrm{HNSCC}$ 에 대한 유도항암요법(NCT01732640), CCRT 이후 재발 가능성이 높 은 환자에 대한 추가 사용(NCT01427478), cetuximab과의 병 용투여(NCT02979977)에 대한 연구가 진행 중이며 EGFR, PTEN, HER-2의 변이의 분포를 환자의 조직에서 검사할 예 정이다. Erlotinib을 유도 항암용법으로 단기간 사용하였을 경 
우 완전관해를 보인 환자 1 예를 제외하고는 다른 항암제와의 병용한 3상 연구 이상에서 우월한 효과를 보이지는 못했다.27) Dacomitinib, gefitinib, lapatinib, vandetinib은 HNSCC에 서 더 이상 연구가 진행되고 있지 않다.

\section{PI3K/Akt/mTOR}

$\mathrm{PI} 3 \mathrm{~K} / \mathrm{Akt} / \mathrm{mTOR}$ 신호 기전은 $\mathrm{G}-$ protein 또는 수용체 tyrosine kinase에 의해 활성화되며 암세포의 분열, 생존, 대사, 이동성에 영향을 미친다. PI3K가 세포막 내부에 위치한 phosphatidylinositol 4,5-biphosphate(PIP2)를 phosphatidylinositol 3,4,5-triphosphate(PIP3)로 변환시키게 되면서 serine/ threonine kinase Akt를 활성화시킨다. ${ }^{28)}$ 활성화된 Akt는 $\mathrm{mTOR}$ 를 활성화시킨다. ${ }^{29}$ 종양억제자인 PTEN은 PIP2에서 PIP3로 변환되는 과정을 조절하며 PTEN 발현감소가 HNSCC 를 포함한 여러 고형암에서 관찰된다. ${ }^{30)} \mathrm{PI} 3 \mathrm{~K} / \mathrm{Akt} / \mathrm{mTOR}$ 와 연관된 이상이 $\mathrm{HNSCC}(30 \sim 50 \%)$ 에서 자주 발견되고 있으며 $P I K 3 C A$ 의 돌연변이 혹은 증폭이 가장 많이 발생한다. ${ }^{31,32)}$ $\mathrm{HPV}(-)$ 종양(7 11\%)보다 PIK3CA의 유전자변이가 $\mathrm{HPV}(+)$ 종양(30\%)에서 더 많이 발견되었다. ${ }^{33)} \mathrm{PI} 3 \mathrm{~K}$ 를 억제하여 세포 의 apoptosis를 유도하게 되는데 BKM-120(Buparlisib), PX-866, BYL-719(Alpelisib), copanlisib이 현재 HNSCC에 서 연구되고 있는 약제이다. Buparlisib, PX-866은 paclitaxel 또는 cetuximab과 병용하여 평가하였지만 높은 부작용을 보이거나 우월한 생존율 개선을 보이지 못하였다. 심지어 $P I K 3 C A$ 돌연변이를 보이는 환자에게서도 우수한 반응을 보 이지 못하였다. ${ }^{34}$ Alpelisib은 적은 부작용이 있으며 현재 R/M $\mathrm{HNSCC}$ 에 대하여 cetuximab과의 병용 치료가 연구 중이다 (NCT01602315). Copanlisib은 PI3KCA 변이가 있는 환자에 대하여 cetuximab 병용 치료에 대해서 연구가 진행 중이다 (NCT02822482). mTOR 억제제는 rapamycin을 시작으로 rapamycin analogs(rapalogs)로서 everloimus, temsirolimus 가 개발되었다. ${ }^{35)} 1990$ 년대 후반부에 이르러서야 신장암, 림 프종에 대한 항암 효과를 연구하기 시작되었다. ${ }^{36)}$ 이 계통 약 제들의 R/M HNSCC에 대한 연구에서 골수억제의 부작용 과 점막염으로 인해서 많은 진전은 보이지 않았다. ${ }^{37}$ 국소적 으로 진행한 $\mathrm{HNSCC}$ 에 대해서 유도항암요법과 연관한 연구 (NCT01133678, NCT00935961)가 진행되었고 완전관해의 소견을 보인 환자도 있었다(NCT01195922). ${ }^{38)}$ Temsirolimus 는 platinum, cetuximab 치료에 반응을 보이지 않았던 환자 에게서 12 주에 이르러 $40 \%$ 의 PFS를 보였다(TEMHEAD, $\mathrm{NCT} 01172769){ }^{39)}$ 다른 대부분의 연구는 부작용과 환자의 사 망으로 인해 연구가 조기에 종료되었으며 장기이식 후 면역 억제제로서의 역할을 하고 있다. ${ }^{40)}$

\section{IL-6/JAK/STAT3}

IL-6/JAK/STAT3 신호체계는 만성 염증과 HNSCC와 같 은 고형암에서 활성도가 증가되어 있다. ${ }^{41)} \mathrm{IL}-6$ 의 결합으로 IL-6, IL-6R, gp130 복합체에 의해서 JAK 효소와 STAT3 전사 인자가 활성화되면 암세포의 분열과 생존이 증가한다. 게다가 IL-6의 자극은 PI3K/Akt/mTOR 신호체계와 RAS/ $\mathrm{RAF} / \mathrm{MEK} / \mathrm{ERK}$ 신호체계를 활성화시킨다. STAT3는 neutrophils, natural killer(NK) cells, effector T-cells, dendritic cells를 억제하며 면역을 억제하는 myeloid-derived suppressor cells(MDSC), regulatory T-cell의 분포를 증가시킨다. 그 러므로 IL-6/JAK/STAT3 신호를 억제하면 직접적인 종양 억 제 효과와 종양을 억제하는 면역체계를 활성화시킨다. IL-6를 억제하는 siltuximab, sirukumab, olokizumab, clazakizumab, MEDI5117, IL-6R $\alpha$ 를 억제하는 tocilizumab, sarilumab이 $\mathrm{HNSCC}$ 에 대한 임상 연구가 진행되고 있다. ${ }^{41)}$ Ruxolitinib은 $\mathrm{JAK} 1 / 2$ 억제제로서 수술이 가능한 HNSCC에 대해서 유도항 암요법으로서 약동학을 연구 중이다(NCT03153982). STAT3 를 억제하기 위해서 decoy oligonucleotide(NCT00696176), AZD9150(NCT02499328), C188-9(NCT03195699) 등이 사용 되고 있다. AZD9150와 durvalumab와의 병합이 durvalum$\mathrm{ab}$ 단독 치료보다 높은 반응률을 보였다. ${ }^{42)}$ 현재는 면역관문 억제제와 IL-6/JAK/STAT3 억제제와의 변합을 통한 연구가 진행되고 있다.

\section{Vascular endothelial growth factor}

저산소증은 혈관증식을 유발하는 vascular endothelial growth factor(VEGF)를 과발현시켜서 HNSCC의 이동과 원 격전이를 촉진시키며 방사선 치료에 대한 반응성을 감소시킨 다. ${ }^{43)}$ Bevacizumab, sorafenib, sunitinib, vandetanib, pazopanib, axitinib이 사용되고 있으며 bevacizumab이 malignant glioma에 대해서 처음 FDA 허가를 받았다.44) Bevacizumab과 erlotinib의 병합으로 $15 \%$ 의 완전관해 소견을 보였 다. ${ }^{45)}$ Cetuximab과의 병합으로는 생존율의 개선을 보이지 않 았으며, ${ }^{46)}$ 전이가 없는 진행된 병기의 $\mathrm{HNSCC}$ 에 대해서 $\mathrm{cis}^{-}$ platin과 intensity modulated RT를 같이 사용할 경우 $75 \%$ 의 2년 PFS, $88 \%$ 의 2년 OS의 소견을 보였다. ${ }^{47)} 5-\mathrm{FU}$ 와 platinum 계열 약제와의 병합에서는 ORR이 $11 \%, \mathrm{PFS}$ 가 2개월 정도 개선되는 효과를 보였으나 OS의 개선은 보이지 않았다. ${ }^{48)}$ $\mathrm{HNSCC}$ 에서 혈관 생성이 중요한 표적이 될 수 있을 것으로 생각되지만 실제로 sorafenib, vandetanib, axitinib, sunitinib 은 HNSCC 환자에 대한 임상 시험 결과가 좋지 않아서 활발 한 연구가 진행되고 있지 않다. 
Cyclin D-CDK4/6-INK4/Rb pathway

암의 특징 중 한 가지가 조절되지 않는 세포 분열이며 이러 한 과정에 관여하는 신호체계가 중요한 표적 치료의 대상이 될 수 있다. Cyclin D-CDK4/CDK6/Rb 신호 체계에서 CDKs 는 cylcin과의 작용을 통해서 G1기에서 $\mathrm{S}$ 기로 이행되는 과 정을 조정한다. ${ }^{49}$ 과발현된 cyclin $\mathrm{D}$ 와 $\mathrm{CDK} 4 / 6$, 또는 cyclin $\mathrm{D} / \mathrm{CDK} 4 / 6$ 의 억제조절자인 p16INK4A의 감소가 암세포에 서 흔히 관찰되며 결국 $\mathrm{Rb}$ 의 인산화를 통한 억제가 유발되 어 세포주기의 진행이 비정상적으로 지속된다. ${ }^{50)} \mathrm{TCGA}$ 분석 을 통해서 $C C D N 1$ (cyclin D1를 코딩)의 증가(31\%) $C D K N 2 A$ (p16 ${ }^{\mathrm{INK4A}}$ 을 코딩) 억제 변이(22\%)가 HNSCC에서 발견되었 다.) Palbociclib, ribociclib은 CDK4, CDK6를 모두 억제하 며 abemaciclib은 CDK4를 선택적으로 억제한다. ${ }^{51)} \mathrm{Palbo}-$ ciclib은 진행된 고형암 환자의 $27 \%$ 에서 안정된 상태를 유도 할 수 있었으나, 부작용으로 호중구 감소, 구역, 피로감, 설사, 점막염, 무력증이 있다. ${ }^{52)}$ Ribociclib도 호중구, 림프구, 백혈 구의 감소가 발생하였다. ${ }^{53)}$ Abemaciclib은 구강으로 섭취가 가능하며 드물게 호중구 감소증이 발생하였고 설사와 오심, 구토의 증상은 흔히 발생하였다. ${ }^{54)} \mathrm{CDK} 4 / 6 / \mathrm{Rb}$ 신호체계의 이상은 $\mathrm{HPV}(+) \mathrm{HNSCC}$ 의 특징이다. $\mathrm{E} 7$ 종양단백질이 $\mathrm{Rb}$ 를 억제하여 $\mathrm{p} 16$ 을 증가시키는데 여기서 $\mathrm{p} 16$ 은 $\mathrm{CDK} 4 / 6$ 억제제 로 작용한다. ${ }^{55)}$ 그러므로 $\mathrm{CDK} 4 / 6$ 억제제는 $\mathrm{HPV}$ 와 연관된 $\mathrm{HNSCC}$ 에 효과가 없을 것으로 생각이 되었으며 초기 임상 시 험에서도 $\mathrm{p} 16^{\mathrm{INK} 4 \mathrm{~A}}(-)$ 종양은 부분관해, $\mathrm{p} 16^{\mathrm{INK4A}}(+)$ 종양은 반 응이 없거나 병변이 진행하는 경우가 있어서 이후 연구에서는 $\mathrm{p} 16^{\text {INK4A }}(-)$ HNSCC 환자를 주로 대상으로 하고 있다. ${ }^{56)}$ Platinum 저항성이 있고 cetuximab으로 치료받지 않은 $\mathrm{HPV}(-)$ $\mathrm{R} / \mathrm{M}$ HNSCC를 대항으로 palbociclib+cetuximab 연구가 진 행되었으며 RR은 $35 \%, \mathrm{PFS}$ 는 6.4개월, OS는 12.1개월이었 다. ${ }^{57)}$ Palbocicilib+platinum(NCT03194373), cetuximab+RT
(NCT03024489), gedatolisib(NCT03065062) 조합에 palbociclib을 추가하는 연구가 진행되고 있으며 절제 가능한 $\mathrm{HPV}(-)$ $\mathrm{HNSCC}$ 환자의 표지자를 찾기 위한 연구가 같이 진행 중이다 (NCT03179956). Abemaciclib는 platinum 기반 치료에 저항 성을 보이는 R/M HNSCC 환자를 모집하여 연구를 진행할 계획이다(NCT03356587).

\section{면역 치료제}

종양 주위의 억제된 면역체계를 회복시키거나 면역세포를 직접적으로 자극할 수 있다(Table 2). 이에 관한 연구를 바탕 으로 면역 치료제 혹은 면역 항암제라는 이름으로 여러 가지 약제가 개발되어 연구가 진행 중이다.

\section{$\mathrm{PD}-1 / \mathrm{PD}-\mathrm{L} 1$ 신호체계}

정상적인 상황에서는 $\mathrm{T}$ 세포는 종양을 항원으로 인지하여 종양세포를 공격한다. T세포의 표면에 발현하는 면역관문 (immune checkpoint) 단백질인 programmed cell death protein-1(PD-1) 또는 cytotoxic T lymphocyte-associated antigen-4(CTLA-4)이 종양세포의 표면에 위치한 PD-L1 혹은 $\mathrm{CD} 80$ (CD86)과 각각 결합할 경우 종양 주위의 면역 환경이 억 제(immunosuppressive)되고 세포독성(cytotoxic) $\mathrm{T}$ 세포의 작 용을 억제하거나 세포가 주위에 모이지 않도록 한다(Fig. 2). ${ }^{58)}$ 이중에서도 단일클론 항체인 anti-PD-1 항체가 PD-1/PD-L1 의 상호작용을 억제하게 되어 종양 주위의 면역 환경이 억제 되지 않도록 한다. ${ }^{59)}$ Nivolumab 또는 pembrolizumab이 R/M $\mathrm{HNSCC}$ 를 포함한 여러 고형암의 생존율을 개선시킨다는 연 구를 바탕으로 현재 R/M HNSCC에 대한 2차 약제로 권장 되고 있다. ${ }^{60-62)} \mathrm{HNSCC}$ 의 미세 환경은 면역이 억제된 상태이 기 때문에 이러한 환경을 개선하여 면역이 자극된 상태로 만 들기 위한 연구가 동반되고 있다. ${ }^{63)}$ Nivolumab은 완전히 hu-

Table 2. Immunotherapeutic agents currently available for head and neck squamous cell carcinoma according to the mechanism of action

\begin{tabular}{|c|c|c|c|}
\hline \multicolumn{2}{|r|}{ Immune-inhibition } & \multicolumn{2}{|c|}{ Immune-stimulation } \\
\hline Target molecules & Drugs & Target molecules & Drugs \\
\hline PD-1 & Nivolumab, pembrolizumab & OX40 & $\begin{array}{l}\text { MEDI6469, INCAGN01949, MEDI6383 } \\
\text { PF04518600 }\end{array}$ \\
\hline PD-Ll & Atezolizumab, durvalumab, avelumab & GITR & INCAGN01949, TRX518, MEDI1873 \\
\hline CTLA-4 & Ipilimumab, tremelimumab & CD27 & Varlilumab \\
\hline LAG-3 & Relatlimab & CD40 & PF04518600 \\
\hline KIR & Lirilumab & 4-1BB (CD137) & CDX-1140 \\
\hline IDO & Epacadostat & TLR-8 & Utomilumab \\
\hline \multirow[t]{3}{*}{ CSFIR } & Pexidartinib, cabiralizumab & TLR-9 & Motolimod, SD-101 \\
\hline & & Oncolytic virus & T-VEC \\
\hline & & Adoptive T-cell therapy & CAR-T, NK cells \\
\hline
\end{tabular}

IDO: indoleamine 2,3-idoxygenase 


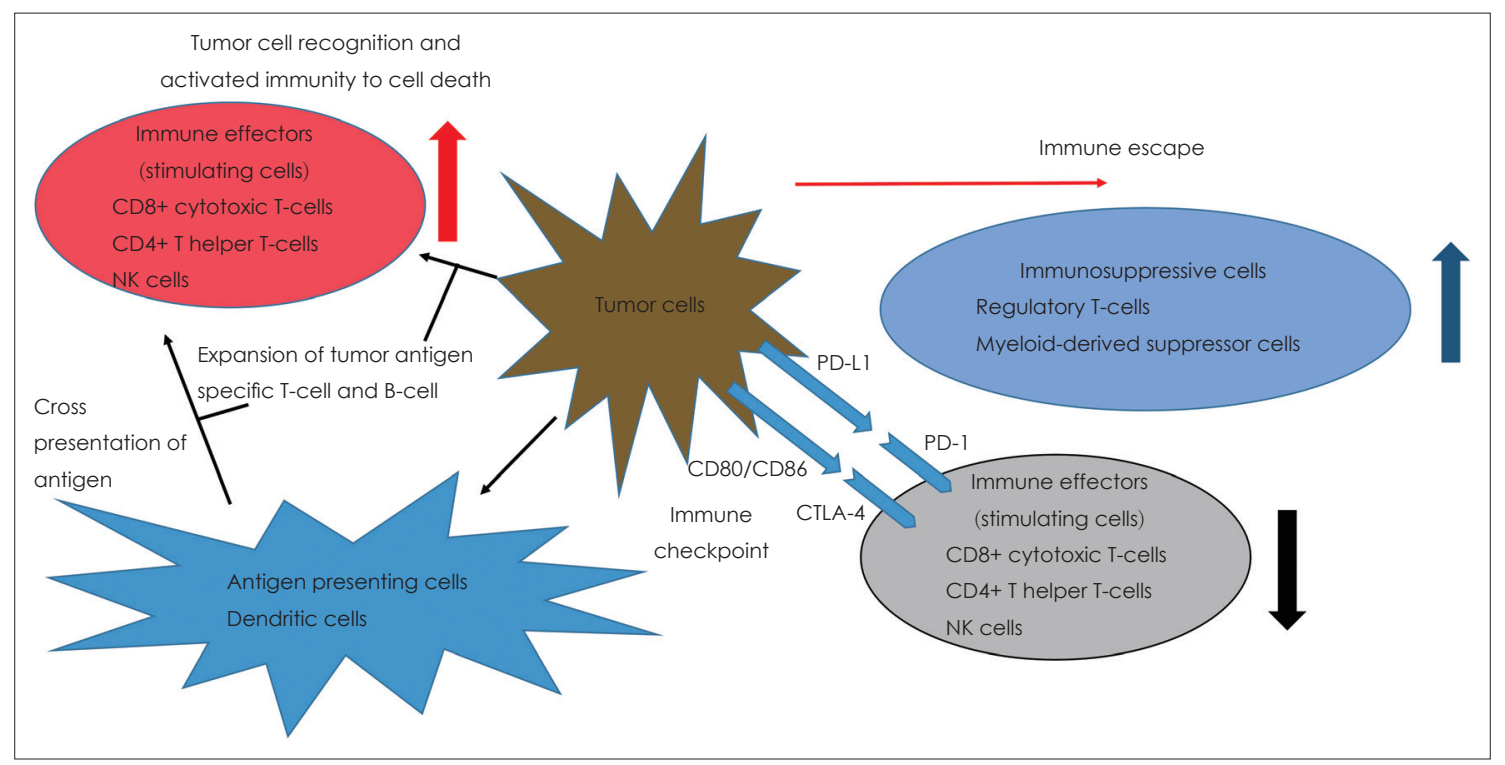

Fig. 2. Immune escape in tumor microenvironment of head and neck squamous cell carcinoma.

manized IgG4, pembrolizumab은 humanized IgG4 단일클 론 항체이다. R/M HNSCC에 대한 3상 연구에서는 nivolum$\mathrm{ab}$ (7.7개월 vs. 5.1개월)과 pembrolizumab(8.4개월 vs. 7.1개월) 이 기존의 항암제와 비교하였을 때 OS의 개선 효과를 보였 다. ${ }^{64,65)}$

KEYNOTE-012 연구는 pembrolizumab을 HNSCC에 사 용하였을 때의 결과를 분석하였다. 60명의 PD-L1(+) HNSCC 환자로 시작하여 $\mathrm{PD}-\mathrm{L} 1$ 의 상태와 상관없이 132 명의 R/M $\mathrm{HNSCC}$ 환자로 확대되었다. 전체 환자의 ORR은 $18 \%[\mathrm{HPV}$ (+); $25 \%, \mathrm{HPV}(-) ; 14 \%]$ 였으며 1명의 환자에게서 완전관해 의 소견을 보였다. ${ }^{66)}$ 반응을 보인 환자의 $82 \%$ 에서 반응이 6 개월 이상 지속되었으며 이는 HPV의 상태에 의해서 영향을 받지는 않았다. 중간 반응 기간과 OS는 각각 12 개월과 13 개 월이었다. 확장된 연구에서 4 명이 완전관해의 소견을 보였으 며 전체 반응율은 $18 \%$ 였고 $\mathrm{HPV}(+)$ 인 환자에게서 개선된 반 응율을 보였으며 ORR은 PD-L1(+) 환자군(22\%)에서 PD$\mathrm{L} 1(-)$ 환자군(4\%)보다 더 좋았다. ${ }^{67)} 2 \%$ 이상의 환자에게서 폐 렴, 호흡곤란, 흥수, 오심, 구토, 호흡 부전이 발생하였다. 치료 를 받고 병변이 진행하지 않았던 환자는 24 개월간 치료를 받 았다. 연구에 포함된 환자들이 이전에 많은 항암 치료와 여러 치료를 받았던 점을 고려한다면 우수한 치료 성적이라 생각 할 수 있으며 이러한 연구결과를 바탕으로 R/M HNSCC 환 자의 2차 약제로 pembrolizumab을 2016년 8월 5일에 FDA 승인을 받았다. 이후 KEYNOTE-040 연구에서 pembrolizumab과 항암치료(methotrexate, docetaxel, or cetuximab) 와의 비교 연구에서 PFS의 개선은 없었지만 ORR은 pembrolizumab(14.6\%)에서 기존의 항암치료(10.1\%) 환자군보다
개선된 효과를 보였으며 $\mathrm{PD}-\mathrm{L1}(+)$ 일 경우 PD-L1(-)보다 반 응율이 더 좋았다. Grade 3,4 의 부작용은 pembrolizumab 환 자(13.4\%)에서 항암 치료 환자(36.3\%)보다 적게 발생하였다. ${ }^{64)}$ KEYNOTE-048에서는 pembrolizumab 단독 치료와 pembrolizumab에 항암 치료제(5-FU, 또는 cetuximab+platinum+ 5-FU)를 병합한 연구가 진행 중이다(NCT02358031). ${ }^{68)}$ Platinum과 cetuximab에 대해 저항성을 보이는 R/M HNSCC 환 자에게 pembrolizumab을 사용하였을 경우 ORR은 $16 \%$, 중 간 반응 기간은 8개월이었다(KEYNOTE-055). ${ }^{69)} \mathrm{HPV}$ 상태 나 PD-L1 발현율이 결과에 영향을 주지는 않았다. 2019년 $\mathrm{NCCN}$ guideline에서 pembprolizumab과 platinum, 5-FU 의 병합요법이 R/M HNSCC에 대한 치료로 platinum/5-FU/ cetuximab과 함께 우선 권장되고 있다.

CheckMate-141에서 R/M HNSCC 환자를 대상으로 nivolum$\mathrm{ab}$ 을 이용한 3상 연구를 통해 약제의 안정성과 효과를 평가 하였다. ${ }^{70)}$ 기존 항암 치료에 비해 nivolumab은 OS를 2.4개월 개선시켰으며 12 개월(34\% vs. $19.7 \%$ )과 18개월(21.5\% vs. 8.3\%) 의 OS 또한 항암제에 비해 개선되었다. $\mathrm{HPV}(+)$ 환자에게서 더 좋은 반응을 보였다. 이러한 결과를 바탕으로 $\mathrm{FDA}$ 와 $\mathrm{EMA}$ 에서 nivolumab을 platinum에 반응하지 않는 R/M HNSCC 에 대한 2차 약제로 승인을 하였다.1) 약제의 교차사용을 통해 서도 nivolumab을 사용한 환자의 PFS 또한 항암제를 사용한 환자보다 개선됨을 확인하였다. Nivolumab(13.3\%)의 ORR이 항암제 치료군(5.8\%)보다 개선되었으며 부작용 또한 nivolum$\mathrm{ab}(13.1 \%)$ 이 항암제 치료군(35\%)보다 낮았다. ${ }^{72)}$ 2019년 NCCN guideline에 의하면 pembrolizumab과 달리 nivolumab 단독 요법은 R/M HNSCC에 대해서 2차 약제로 권장되고 있다. 
흑색종과 다른 고형암에서 PD-L1을 억제하였을 때 PD-1 을 억제한 결과와 비슷한 결과를 보였다. ${ }^{73)}$ 이러한 결과가 atezolizumab, durvalumab, avelumab과 같은 anti-PD-L1 항체의 $\mathrm{HNSCC}$ 에 대한 연구로 확장시켰다. Atezolizumab를 R/M HNSCC에 사용한 연구에서 ORR은 22\%였으며 PFS와 $\mathrm{OS}$ 가 각각 2.6개월과 6개월이었다(NCT01375842). ${ }^{74)} \mathrm{HPV}$ 와 의 연관성은 발견하지 못했다. Durvalumab을 이용한 연구에 서는 2.3개월은 $\mathrm{PFS}$ 와 $\mathrm{HPV}(+), \mathrm{HPV}(-)$ 환자들이 각각 $26.5 \%$ 와 $7.9 \%$ 의 ORR을 보였다. ${ }^{75)}$ 심각한 부작용 (grade 3 이상)은 $9.8 \%$ 에서 발생하였다. PD-L1(-) R/M HNSCC를 대상으로 CONDOR trial에서 durvalumab 단독 치료와 tremelimum$\mathrm{ab}$ (anti-CTLA-4 agent)와의 병용 치료의 결과를 확인하였다 (NCT02319044). ${ }^{76}$ 단독요법(6.0개월)보다 병합 치료(7.6 months) 에서 OS가 개선됨을 확인하였다. Avelumab을 HNSCC에서 사용한 연구는 아직 보고가 되지 않았다. 대부분의 anti-PD$\mathrm{L} 1$ 약제는 다른 면역 약제와의 병합 치료 효과를 평가하는 임상 연구가 진행 중이다(NCT02952586, NCT03260023, NCT02999087, and NCT01772004).

\section{CTLA-4 신호체계}

Ipilimumab은 CTLA-4를 억제하는 fully humanized IgG1 단일 항체이며 진행된 흑색종에서 처음 적용되었다. ${ }^{77)}$ 흑색종 에서의 우수한 결과를 바탕으로 ipilumumab과 nivolumab 과의 병합요법이 $\mathrm{HNSCC}$ 를 포함한 진행된 고형암을 대상 으로 연구가 진행 중이다(NCT02919683, NCT03126110, NCT03241173). Tremelimumab과 durvalumab과의 병합 치 료(NCT02262741, NCT03450967)와 durvalumab(anti-PDL1) 단독과 tremelimumab과 병합 또는 항암제(carboplatin 또는 cisplatin+5-FU+cetuximab)와의 병합 치료 연구가 R/M HNSCC 환자를 대상으로 진행 중이며(NCT02551159; KESTREL, NCT02369874: EAGLE) 단독 치료로는 사용되지 않 고 있다.

\section{다른 면역 치료약제}

$\mathrm{T}$ 세포 수용체(T-cell receptor)에 의해서 항원표현세포 (antigen presenting cell, APC)의 표면에 나타나는 major histocompatibility(MHC) molecules이 되어야 T세포가 활성 화된다. 보조적으로 자극하는 물질이 있으면 $\mathrm{T}$ 세포의 완전한 활성화를 위해 필요하다. 면역 환경을 자극시키는 $\mathrm{TNF}$ 수용 체(OX40, 4-1BB, GITR, CD27, CD40)에 대한 자극 항체(agonistic antibody)가 종양 주위의 면역 상태를 자극하여 항암 효과를 발생시킨다. ${ }^{78)}$ 이에 대한 연구는 대부분 진행된 HNSCC 를 포함한 고형암을 대상으로 임상 연구가 진행되고 있다. OX40 agonist는 T세포에서 cytokine을 발생시켜 세포를 사멸하게 만든다. MEDI6383, 9B12, MEDI6469, INCAGN01949가 여 기에 해당된다. Glucocorticoid-induced tumor necrosis factor receptor(GITR)은 $\mathrm{APC}$ 와 $\mathrm{CD}^{+} \mathrm{T}$ 세포에서 표현되며 면 역 자극제의 역할을 하며 FoxP3와 IL-10의 발현을 줄여서 Treg와 연관된 면역 억제 작용을 방해하고 $\mathrm{CD}^{+} \mathrm{T}$ 세포를 증 가시킨다. ${ }^{79)}$ Agonistic anti-GITR 항체(INCAGN01876; NCT 03277352, NCT03126110, TRX518/MEDI1873; NCT02628574, NCT01239134)와 anti-PD-1 또는 anti-CTLA4 항체와의 병 합요법 임상 시험이 진행 중이다. 4-1BB(CD137) 단백질은 $\mathrm{CD}^{+}, \mathrm{CD}^{+} \mathrm{T}$ 세포와 $\mathrm{NK}$ 세포에서 발현된다. Utomilumab은 4-1BB를 자극하여 T세포와 연계한 항암 작용을 촉진한다. ${ }^{80}$ Avelumab과의 병용 연구가 진행 중이다(NCT02554812). Varlilumab은 agonistic anti-CD27 항체이며 nivolumab과 의 병용 치료(NCT02335918)가 시도 중이며 agonistic CD40 항체인 dacetuzumab과 lucatumumab은 아직 HNSCC에 적 용되지 않고 있다.

Lymphocyte-activation gene-3(LAG-3)과 killer-cell immunoglobulin-like receptors(KIRs)은 면역관문 단백질 (checkpoint protein)이며 각각 림프구와 NK세포와 연관된 세포독성을 억제한다. Relatlimab(anti-LAG-3)+nivolumab (NCT01968109), lirilumab(anti-KIRs)+nivolumab(또는 ipilimumab)을 진행되거나 전이성 고형암에 대한 연구에 적 용 중이다(NCT03341936, NCT03347123). Lirilumab과 nivolumab의 병용 치료는 $24 \%$ 의 ORR을 보였으며 PD-L1(+) 종양의 치료 결과가 가장 좋았다. ${ }^{81)}$

Indoleamine-pyrrole 2,3-dioxygenase(IDO)은 종양 주 위의 tryptophan을 감소시켜서 kynurenine의 생산을 유도한 다. 이를 통해 면역 억제 기능이 있는 Tregs과 MDSC를 증가 시키며 종양 주위의 면역 억제 기능을 유발한다. Epacadostat (IDO 억제제)와 pembrolizumab을 HNSCC을 사용하였을 때 효과를 평가 중이며(NCT02178722; ECHO-202/KEYNOTE-037), $34 \%$ 의 ORR과 $62 \%$ 의 DCR 결과를 보였다. 이 러한 1,2 상 연구를 바탕으로 3상 연구가 계획 중이다.

Toll-like receptors(TLRs)은 자연(innate) 면역과 적응 (adaptive) 면역 모두 관여한다. Motolimod(VTX-2337)은 TLR-8 agonist로서 MDSC, monocytes, NK세포를 자극한 다. R/M HNSCC를 cetuximab과 사용하였을 경우 $17 \%$ 의 RR과 54\%의 DCR을 보였다. ${ }^{82}$ SD-101은 TLR-9 agonist는 interferon $-\alpha$ 를 생산하여 NK세포와 $\mathrm{CD}^{+}{ }^{+}$T세포를 종양 주 위로 모이게 한다. SD-101를 종양에 직접 주입하면서 pembrolizumab을 R/M HNSCC 환자에게 사용하는 연구가 평 가 중이다(NCT02521870). Adoptive T-cell therapy(ACT)는 
환자의 말초 혈액 또는 종양에서 T세포 또는 TILs을 분리하 여 체외에서 확장시킨 뒤 환자에게 다시 주입하는 방법이다. 체외에서 확장할 때 $\mathrm{T}$ 세포를 유전적으로 가공을 하여 면역 기능을 강화시킬 수도 있다. R/M HNSCC를 대상으로 ACT에 대한 1상 임상 연구에서 환자를 모집하고 있다(NCT03247309).

$\mathrm{HNSCC}$ 에 대한 국소 치료를 통해서 출혈, 감염, 기도폐쇄, 연하장애를 개선시킬 수 있으리라는 가정하에 다른 면역 치료 방법을 고려할 수 있다. 백신, chimeric antigen receptor(CAR) $\mathrm{T}$ 세포, 유전자 변형을 통한 바이러스가 적용될 수 있다. 암백 신은 면역관문 수용체를 억제하여 세포독성 $\mathrm{T}$ 세포의 증식을 유발한다. 펩타이드를 기반으로 한 ISA101은 HPV-16으로부 터 기원한 바이러스 치료제로서 nivolumab과 병합하여 치 료에 반응이 없는 HPV-16(+) 환자를 대상으로 2상 연구가 진행 중이다. ${ }^{83)}$ ISA101와 nivolumab을 병합할 경우 CheckMate-141에서 보였던 nivolumab 단독 치료에 비해 더 좋은 $36 \%$ 의 ORR의 소견을 보였다. 핵산(nucleic acid)을 기반으 로 한 INO-3112, INO-9012와 벡터 기반 ADXS11-001이 최 근 $\mathrm{HNSCC}$ 환자를 대상으로 연구를 시작하였다. ${ }^{84)} \mathrm{Talimo-}$ gene Laherparepvec(T-VEC, IMLYGIC ${ }^{\mathrm{TM}}$ )은 HSV-1에서 기원하였으며 FDA로부터 허가를 받은 종양분쇄(oncolytic) 바이러스 치료제이다. 처음에는 진행된 흑색종을 대상으로 허 가를 받았으며 R/M HNSCC를 대상으로 T-VEC과 pembrolizumab의 병용 치료가 최근 평가 중이다(MASTERKEY232/ KEYNOTE-137, NCT02626000).

\section{연구 방향}

세포신호 전달기전 또는 면역체계와 연관된 치료 약제를 단 독으로 사용하는 것보다 병합 치료에 대한 연구가 진행 중이 다. 그리고, 표적 치료, 면역 치료에 대한 저항기전을 밝혀 내어 이와 연관된 표지자를 치료 전 생체표지자로서 사용할 수도 있고 이를 극복하는 치료 방법을 개발하는 데 도움을 줄 수 있 다. 그 예로, cetuximab과 같은 EGFR을 표적으로 하는 약제 의 저항성은 ErbB2/HER-2의 활성화와 변이형 EGFR type III(EGFRvIII)의 과발현과 연관되었다. ${ }^{85)}$ 이밖에 EMT와 연관 된 단백질, 약제 사용 후 보상기전으로 발현하는 VEGF, MET, Notch, PI3K/Akt/mTOR, JAK/STAT3 신호기전이 EGFR 억제제에 대한 저항성과 연관되어 있다. ${ }^{86)}$ 이러한 연구를 바탕 으로 HGF/c-MET 신호기전을 억제하는 ficlatuzumab(AV299)을 이용한 연구가 R/M HNSCC 환자를 대상으로 연구가 진행되고 있다(NCT02277197, NCT03422536). 하지만 cetuximab에 대하여 기대보다 적은 효과를 보이는 원인이 명확하 게 밝혀진 것은 아니다.

최근에는 면역 치료제에 대한 연구가 활발하게 진행되고 있
어서 어떠한 면역 환경이 면역 치료에 적합한지 밝히기 위한 연구가 치료 평가와 함께 시행되고 있다. PD-L1의 발현이 높 거나 종양 주위에 면역세포의 침착이 많은 경우와 종양의 유 전변이가 많을수록(high mutational burden, high gene expression profile score) 면역관문 억제제에 반응이 좋았다. ${ }^{87)}$ 다른 면역체계에 대한 연구도 진행되고 있는데, 면역을 억제 하는 cytokines으로 TGF- $\beta$, IL-6, and IL-10, GM-CSF, $\mathrm{MCP}-1, \mathrm{CXCL1}, \mathrm{IL}-8, \mathrm{CSF} 1$ 이 알려져 있으며 MDSC를 $\mathrm{HNSCC}$ 주위로 모이게 유도한다 ${ }^{88)} \mathrm{MDSC}$ 는 arginase 1(Arg1), nitric oxide synthase(iNOS), reactive oxygen species $(\mathrm{ROS})$ 를 분비하여 $\mathrm{T}$ 세포의 기능을 억제한다. ${ }^{89)}$ 이러한 과정 에 관여하는 IDO 억제제(epacadostat), STAT3 억제제(decoy, OPB-51602, OPB-31131, AZD9150), phosphodiesterase 5( $\left.\mathrm{PDE}_{5}\right)$ 억제제(taldalafil, sildenafil)가 이러한 MDSCs 의 작용을 억제할 수 있다. 이러한 표지자를 이용한 약제 개 발 이외에 기존의 항암제, 방사선 치료, 표적 치료제와의 조합 을 통한 치료 결과의 개선을 추구하고 있다. 이러한 치료를 통 해 종양의 항원성을 증가시키고 염증을 유발해서 면역반응을 자극하려는 연구가 있다. ${ }^{90)}$ 방사선 치료를 근간으로 anti-PD-1 항체 약제와의 병용 연구가 진행 중이다(NCT02609503, NCT02586207, NCT02289209, and NCT02318771).

이전 면역 치료에 대한 연구는 R/M HNSCC 환자를 대상 으로 주로 연구를 진행하였다. 수술적으로 제거가 가능한 환 자를 대상으로 pembrolizumab을 유도항암요법의 개념으로 사용하는 연구가 시작되었다(NCT02296684). Pembolizumab 으로 치료받은 $48 \%$ 의 환자에서 종양의 크기가 감소됨이 관 찰되었다. 수술 전 조직에서 $\mathrm{PD}-\mathrm{L} 1(+)(>1 \%$ 종양세포)이 $58 \%$ 에서 발현되었으며 이들 환자들이 반응율이 더 좋았다. ${ }^{91)}$ 이 와 유사하게 수술로 절제가 가능한 HNSCC 환자에게 수술 전 nivolumab을 사용하였을 때 안정성과 치료 효과를 평가 한 연구가 진행되었다(CheckMate-358; NCT02488759). Grade 3, 4의 부작용은 $16.7 \%$ 에서 발견되었으나 수술을 연 기한 경우는 없었다. 수술 전 종양의 크기 감소는 $48 \%$ 의 환 자에게서 발생하였고 $13 \%$ 의 환자는 종양의 크기가 $40 \%$ 이 상 감소하였다. ${ }^{92)}$ 이러한 결과를 바탕으로 면역 치료제의 적 용 범위가 더 확대될 것으로 생각한다.

EGFR을 표적으로 하는 항체인 cetuximab, TKI인 afatinib 이외에 anti-PD-1 항체인 nivolumab, pembrolizum$\mathrm{ab}$ 이 최근에 $\mathrm{HNSCC}$ 의 치료를 위해 추가된 약제이다. 최근 정밀의료의 발전과 $\mathrm{HPV}(+)$ 종양에 대한 깊은 이해를 바탕으 로 새로운 표적이 되거나 환자에 맞는 치료법이 개발되고 있 다. 치료 성적을 높이기 위해서, 예전보다 HNSCC에서 변이 를 정확하게 발견하고 이에 맞는 표적 치료제를 적절히 사용 
하려고 시도하고 있다. 이와 동시에 종양에 대한 면역 환경의 중요성이 대두됨에 따라서 면역 치료기법이 시도되고 있지만 특정 환자에게만 도움이 되기 때문에 적합한 환자를 찾아내 는 생체표지자 연구가 진행되고 있다. 억제된 면역 환경을 개 선하기 위한 다양한 표적이 개발되고 있으며 항원성을 증가 시키기 위한 병합 치료에 대한 임상 연구가 활발하게 진행되 고 있다. $\mathrm{HNSCC}$ 의 면역 상태를 정밀의료 분석 기법을 통해 환자에게 알맞는 면역 치료를 시행하는 precision immunotherapy의 개념으로 환자를 치료할 수 있을 것으로 예상하 며 현재보다 우수한 치료 성적을 나타낼 것으로 기대한다.

\section{Acknowledgments}

This work was supported by Grants from National Research Foundation of Korea (NRF) (grant number MSIP; 2016R1C1B1014827).

\section{ORCID}

Yoon Se Lee https://orcid.org/0000-0001-6534-5753

\section{REFERENCES}

1) International Agency for Research on Cancer. World cancer report 2014. Lyon: International Agency for Research on Cancer;2014.

2) Benson E, Li R, Eisele D, Fakhry C. The clinical impact of HPV tumor status upon head and neck squamous cell carcinomas. Oral Oncol 2014;50:565-574.

3) International Cancer Genome Consortium, Hudson TJ, Anderson W, Artez A, Barker AD, Bell C, et al. International network of cancer genome projects. Nature 2010;464(7291):993-8.

4) Agrawal N, Frederick MJ, Pickering CR, Bettegowda C, Chang K, Li RJ, Fakhry C, et al. Exome sequencing of head and neck squamous cell carcinoma reveals inactivating mutations in NOTCH1. Science 2011;333(6046):1154-7.

5) Stransky N, Egloff AM, Tward AD, Kostic AD, Cibulskis K, Sivachenko $\mathrm{A}$, et al. The mutational landscape of head and neck squamous cell carcinoma. Science 2011;333(6046):1157-60.

6) Cancer Genome Atlas Network. Comprehensive genomic characterization of head and neck squamous cell carcinomas. Nature 2015;517(7536):576-82.

7) Marur S, Forastiere AA. Head and neck cancer: Changing epidemiology, diagnosis, and treatment. Mayo Clin Proc 2008;83(4):489-501.

8) Saloura V, Cohen EE, Licitra L, Billan S, Dinis J, Lisby S, et al. An open-label single-arm, phase II trial of zalutumumab, a human monoclonal anti-EGFR antibody, in patients with platinumrefractory squamous cell carcinoma of the head and neck. Cancer Chemother Pharmacol 2014;73(6):1227-39.

9) Blasco MA, Svider PF, Raza SN, Jacobs JR, Folbe AJ, Saraf P, et al. Systemic therapy for head and neck squamous cell carcinoma: Historical perspectives and recent breakthroughs. Laryngoscope 2017;127(11):2565-9.

10) Zumsteg ZS, Luu M, Yoshida EJ, Kim S, Tighiouart M, David JM, et al. Combined high-intensity local treatment and systemic therapy in metastatic head and neck squamous cell carcinoma: An analysis of the National Cancer Data Base. Cancer 2017;123(23):4583-93.

11) Szabó B, Nelhubel GA, Kárpáti A, Kenessey I, Jóri B, Székely C, et al. Clinical significance of genetic alterations and expression of epidermal growth factor receptor (EGFR) in head and neck squamous cell carcinomas. Oral Oncol 2011;47(6):487-96.

12) Bonner JA, Harari PM, Giralt J, Azarnia N, Shin DM, Cohen RB, et al. Radiotherapy plus cetuximab for squamous-cell carcinoma of the head and neck. N Engl J Med 2006;354(6):567-78.

13) National Comprehensive Cancer Network. NCCN guidelines: Head and neck cancer, version 3 2019. Plymouth Meeting, PA: National Comprehensive Cancer Network INC;2019.

14) Huang J, Zhang J, Shi C, Liu L, Wei Y. Survival, recurrence and toxicity of HNSCC in comparison of a radiotherapy combination with cisplatin versus cetuximab: A meta-analysis. BMC Cancer 2016;16:689.

15) Lee YS, Johnson DE, Grandis JR. An update: Emerging drugs to treat squamous cell carcinomas of the head and neck. Expert Opin Emerg Drugs 2018;23(4):283-99.

16) Leemans CR, Braakhuis BJ, Brakenhoff RH. The molecular biology of head and neck cancer. Nat Rev Cancer 2011;11(1):9-22.

17) Chung CH, Parker JS, Ely K, Carter J, Yi Y, Murphy BA, et al. Gene expression profiles identify epithelial-to-mesenchymal transition and activation of nuclear factor- $\mathrm{kB}$ signaling as characteristics of a high-risk head and neck squamous cell carcinoma. Cancer Res 2006;66(16):8210-8.

18) Schneider-Merck T, Lammerts van Bueren JJ, Berger $S$, Rossen $K$, van Berkel PH, Derer S, et al. Human IgG2 antibodies against epidermal growth factor receptor effectively trigger antibody-dependent cellular cytotoxicity but, in contrast to IgG1, only by cells of myeloid lineage. J Immunol 2010;184(1):512-20.

19) Bonner JA, Harari PM, Giralt J, Cohen RB, Jones CU, Sur RK, et al. Radiotherapy plus cetuximab for locoregionally advanced head and neck cancer: 5 -year survival data from a phase 3 randomised trial, and relation between cetuximab-induced rash and survival. Lancet Oncol 2010;11(1):21-8.

20) Burtness B, Goldwasser MA, Flood W, Mattar B, Forastiere AA; Eastern Cooperative Oncology Group. Phase III randomized trial of cisplatin plus placebo compared with cisplatin plus cetuximab in metastatic/recurrent head and neck cancer: An Eastern Cooperative Oncology Group study. J Clin Oncol 2005;23(34):8646-54.

21) Vermorken JB, Trigo J, Hitt R, Koralewski P, Diaz-Rubio E, Rolland F, et al. Open-label, uncontrolled, multicenter phase II study to evaluate the efficacy and toxicity of cetuximab as a single agent in patients with recurrent and/or metastatic squamous cell carcinoma of the head and neck who failed to respond to platinum-based therapy. J Clin Oncol 2007;25(16):2171-7.

22) Vermorken JB, Mesia R, Rivera F, Remenar E, Kawecki A, Rottey $\mathrm{S}$, et al. Platinum-based chemotherapy plus cetuximab in head and neck cancer. N Engl J Med 2008;359(11):1116-27.

23) Vermorken JB, Stöhlmacher-Williams J, Davidenko I, Licitra L, Winquist E, Villanueva $\mathrm{C}$, et al. Cisplatin and fluorouracil with or without panitumumab in patients with recurrent or metastatic squamous-cell carcinoma of the head and neck (SPECTRUM): An open-label phase 3 randomised trial. Lancet Oncol 2013;14(8):697-710.

24) Sacco AG, Worden FP. Molecularly targeted therapy for the treatment of head and neck cancer: A review of the ErbB family inhibitors. Onco Targets Ther 2016;9:1927-43.

25) Cohen EEW, Licitra LF, Burtness B, Fayette J, Gauler T, Clement $\mathrm{PM}$, et al. Biomarkers predict enhanced clinical outcomes with afatinib versus methotrexate in patients with second-line recurrent and/or metastatic head and neck cancer. Ann Oncol 2017;28(10): 2526-32.

26) Seiwert TY, Fayette J, Cupissol D, Del Campo JM, Clement PM, Hitt $\mathrm{R}$, et al. A randomized, phase II study of afatinib versus cetuximab in metastatic or recurrent squamous cell carcinoma of the head and neck. Ann Oncol 2014;25(9):1813-20.

27) Van Allen EM, Lui VW, Egloff AM, Goetz EM, Li H, Johnson JT, et al. Genomic correlate of exceptional erlotinib response in head and neck squamous cell carcinoma. JAMA Oncol 2015;1(2):238-44.

28) De Felice F, Guerrero Urbano T. New drug development in head and neck squamous cell carcinoma: The PI3-K inhibitors. Oral Oncol 
2017;67:119-23.

29) Laplante M, Sabatini DM. mTOR signaling in growth control and disease. Cell 2012;149(2):274-93.

30) Squarize CH, Castilho RM, Abrahao AC, Molinolo A, Lingen MW, Gutkind JS. PTEN deficiency contributes to the development and progression of head and neck cancer. Neoplasia 2013;15(5):461-71.

31) Lui VW, Hedberg ML, Li H, Vangara BS, Pendleton K, Zeng Y, et al. Frequent mutation of the PI3K pathway in head and neck cancer defines predictive biomarkers. Cancer Discov 2013;3(7):761-9.

32) Seiwert TY, Zuo Z, Keck MK, Khattri A, Pedamallu CS, Stricker $\mathrm{T}$, et al. Integrative and comparative genomic analysis of HPVpositive and HPV-negative head and neck squamous cell carcinomas. Clin Cancer Res 2015;21(3):632-41

33) Chung CH, Guthrie VB, Masica DL, Tokheim C, Kang H, Richmon $\mathrm{J}$, et al. Genomic alterations in head and neck squamous cell carcinoma determined by cancer gene-targeted sequencing. Ann Oncol 2015; 26(6):1216-23.

34) Soulieres D, Faivre SJ, Mesia R, Remenar Eva, Li SH, Karpenko A, et al. BERIL-1: A phase II, placebo-controlled study of buparlisib (BKM120) plus paclitaxel in patients with platinum-pretreated recurrent/metastatic head and neck squamous cell carcinoma (HNSCC). J Clin Oncol 2016;34(15 suppl):6008.

35) Zheng Y, Jiang Y. mTOR inhibitors at a glance. Mol Cell Pharmacol 2015;7(2):15-20.

36) Schedel F, Pries R, Thode B, Wollmann B, Wulff S, Jocham D, et al. mTOR inhibitors show promising in vitro activity in bladder cancer and head and neck squamous cell carcinoma. Oncol Rep 2011;25(3):763-8.

37) Chung CH, Wang H, Tsottles N, Gourin CG, Agrawal N, Molinolo A, et al. A phase I study of everolimus in combination with cetuximab and cisplatin as first-line therapy in recurrent and metastatic $(\mathrm{R} / \mathrm{M})$ head and neck squamous cell carcinoma (HNSCC). J Clin Oncol 2012;30(15 suppl):e16061.

38) Shirai K, Day TA, Szabo E, Van Waes C, O’Brien PE, Matheus MG, et al. A pilot, single arm, prospective trial using neoadjuvant rapamycin prior to definitive therapy in head and neck squamous cell carcinoma. J Clin Oncol 2015;33(15 suppl):6071.

39) Grünwald V, Keilholz U, Boehm A, Guntinas-Lichius O, Hennemann B, Schmoll HJ, et al. TEMHEAD: A single-arm multicentre phase II study of temsirolimus in platin-and cetuximab refractory recurrent and/or metastatic squamous cell carcinoma of the head and neck (SCCHN) of the German SCCHN Group (AIO). Ann Oncol 2015; 26(3):561-7.

40) Bauman JE, Arias-Pulido H, Lee SJ, Fekrazad MH, Ozawa H, Fertig E, et al. A phase II study of temsirolimus and erlotinib in patients with recurrent and/or metastatic, platinum-refractory head and neck squamous cell carcinoma. Oral Oncol 2013;49(5):461-7.

41) Johnson DE, O'Keefe RA, Grandis JR. Targeting the IL-6/JAK/ STAT3 signalling axis in cancer. Nat Rev Clin Oncol 2018;15(4): 234-48.

42) Cohen EE, Hong DS, Wise Draper T, Nassib William W, Schrijvers D, Mesia Nin R, et al. 1135OPhase 1b/2 Study (SCORES) assessing safety, tolerability, and preliminary anti-tumor activity of durvalumab plus AZD9150 or AZD5069 in patients with advanced solid malignancies and squamous cell carcinoma of the head and neck (SCCHN). Ann Oncol 2017;28(Suppl 5):v403-27.

43) Kyzas PA, Cunha IW, Ioannidis JP. Prognostic significance of vascular endothelial growth factor immunohistochemical expression in head and neck squamous cell carcinoma: A meta-analysis. Clin Cancer Res 2005;11(4):1434-40.

44) McGee MC, Hamner JB, Williams RF, Rosati SF, Sims TL, Ng $\mathrm{CY}$, et al. Improved intratumoral oxygenation through vascular normalization increases glioma sensitivity to ionizing radiation. Int J Radiat Oncol Biol Phys 2010;76(5):1537-45.
45) Cohen EE, Davis DW, Karrison TG, Seiwert TY, Wong SJ, Nattam $\mathrm{S}$, et al. Erlotinib and bevacizumab in patients with recurrent or metastatic squamous-cell carcinoma of the head and neck: A phase I/II study. Lancet Oncol 2009;10(3):247-57.

46) Argiris A, Kotsakis AP, Hoang T, Worden FP, Savvides P, Gibson MK, et al. Cetuximab and bevacizumab: Preclinical data and phase II trial in recurrent or metastatic squamous cell carcinoma of the head and neck. Ann Oncol 2013;24(1):220-5.

47) Fury MG, Lee NY, Sherman E, Lisa D, Kelly K, Lipson B, et al. A phase 2 study of bevacizumab with cisplatin plus intensity-modulated radiation therapy for stage III/IVB head and neck squamous cell cancer. Cancer 2012;118(20):5008-14.

48) Argiris A, Ghebremichael M, Gilbert J, Lee JW, Sachidanandam $\mathrm{K}$, Kolesar JM, et al. Phase III randomized, placebo-controlled trial of docetaxel with or without gefitinib in recurrent or metastatic head and neck cancer: An eastern cooperative oncology group trial. J Clin Oncol 2013;31(11):1405-14.

49) Shapiro GI. Cyclin-dependent kinase pathways as targets for cancer treatment. J Clin Oncol 2006;24(11):1770-83.

50) Hamilton E, Infante JR. Targeting CDK4/6 in patients with cancer. Cancer Treat Rev 2016;45:129-38.

51) Asghar U, Witkiewicz AK, Turner NC, Knudsen ES. The history and future of targeting cyclin-dependent kinases in cancer therapy. Nat Rev Drug Discov 2015;14(2):130-46.

52) Flaherty KT, Lorusso PM, Demichele A, Abramson VG, Courtney $\mathrm{R}$, Randolph SS, et al. Phase I, dose-escalation trial of the oral cyclindependent kinase 4/6 inhibitor PD 0332991, administered using a 21-day schedule in patients with advanced cancer. Clin Cancer Res 2012;18(2):568-76.

53) Infante JR, Shapiro G, Witteveen P, Gerecitano JF, Ribrag V, Chugh $\mathrm{R}$, et al. A phase I study of the single-agent CDK4/6 inhibitor LEE011 in pts with advanced solid tumors and lymphomas. J Clin Oncol 2014;32(15 suppl):2528.

54) Shapiro G, Rosen LS, Tolcher AW, Goldman JW, Gandhi L, Papadopoulos KP, et al. A first-in-human phase I study of the CDK4/6 inhibitor, LY2835219, for patients with advanced cance. J Clin Oncol 2013;31(15 suppl):2500.

55) Choschzick M, Hess S, Tennstedt P, Holst F, Bohlken H, Gieseking $\mathrm{F}$, et al. Role of cyclin D1 amplification and expression in vulvar carcinomas. Hum Pathol 2012;43(9):1386-93.

56) Michel L, Ley J, Wildes TM, Schaffer A, Robinson A, Chun SE, et al. Phase I trial of palbociclib, a selective cyclin dependent kinase $4 / 6$ inhibitor, in combination with cetuximab in patients with recurrent/ metastatic head and neck squamous cell carcinoma. Oral Oncol 2016;58:41-8.

57) Adkins D, Oppelt PJ, Ley JC, Trinkaus K, Neupane PC, Sacco AG, et al. Multicenter phase II trial of palbociclib, a selective cyclin dependent kinase (CDK) 4/6 inhibitor, and cetuximab in platinumresistant HPV unrelated (-) recurrent/metastatic head and neck squamous cell carcinoma (RM HNSCC). J Clin Oncol 2018;36(15 suppl):6008.

58) Pardoll DM. The blockade of immune checkpoints in cancer immunotherapy. Nat Rev Cancer 2012;12(4):252-64.

59) Postow MA, Callahan MK, Wolchok JD. Immune checkpoint blockade in cancer therapy. J Clin Oncol 2015;33(17):1974-82.

60) Brahmer J, Reckamp KL, Baas P, Crinò L, Eberhardt WE, Poddubskaya E, et al. Nivolumab versus docetaxel in advanced squamous-cell non-small-cell lung cancer. N Engl J Med 2015;373(2):123-35.

61) Herbst RS, Baas P, Kim DW, Felip E, Pérez-Gracia JL, Han JY, et al. Pembrolizumab versus docetaxel for previously treated, PD-L1positive, advanced non-small-cell lung cancer (KEYNOTE-010): A randomised controlled trial. Lancet 2016;387(10027):1540-50.

62) Robert C, Long GV, Brady B, Dutriaux C, Maio M, Mortier L, et al. Nivolumab in previously untreated melanoma without BRAF 
mutation. N Engl J Med 2015;372(4):320-30.

63) Duray A, Demoulin S, Hubert P, Delvenne P, Saussez S. . Immune suppression in head and neck cancers: A review. Clin Dev Immunol 2010;2010:701657.

64) Cohen EE, Harrington KJ, Le Tourneau C, Dinis J, Licitra L, Ahn MJ, et al. LBA45_PRPembrolizumab (pembro) vs standard of care (SOC) for recurrent or metastatic head and neck squamous cell carcinoma (R/M HNSCC): Phase 3 KEYNOTE-040 trial. Ann Oncol 2017;28(suppl 5).

65) Saba NF, Blumenschein GR, Guigay J, Licitra LF, Fayette J, Harrington KJ, et al. Nivolumab (nivo) vs investigator's choice (IC) in patients (pts) with recurrent or metastatic (R/M)squamous cell carcinoma of the head and neck (SCCHN): analysis of CheckMate 141 by age. J Clin Oncol 2018;36(15 suppl):6028.

66) Seiwert TY, Burtness B, Mehra R, Weiss J, Berger R, Eder JP, et al. Safety and clinical activity of pembrolizumab for treatment of recurrent or metastatic squamous cell carcinoma of the head and neck (KEYNOTE-012): An open-label, multicentre, phase $1 \mathrm{~b}$ trial. Lancet Oncol 2016;17(7):956-65.

67) Chow LQM, Haddad R, Gupta S, Mahipal A, Mehra R, Tahara M, et al. Antitumor activity of pembrolizumab in biomarker-unselected patients with recurrent and/or metastatic head and neck squamous cell carcinoma: Results from the phase Ib KEYNOTE-012 expansion cohort. J Clin Oncol 2016;34(32):3838-45.

68) Klochikhin A, Greil R, Cohen E, Vermorken J, Harrington K, Tahara $\mathrm{M}$, et al. 11TiP Phase 3 trial of pembrolizumab as a first-line treatment in subjects with recurrent/metastatic head and neck squamous cell carcinoma: KEYNOTE-048. Ann Oncol 2015;26(suppl 8):viii5.

69) Bauml J, Seiwert TY, Pfister DG, Worden F, Liu SV, Gilbert J, et al. Pembrolizumab for platinum- and cetuximab-refractory head and neck cancer: Results from a single-arm, phase II study. J Clin Oncol 2017;35(14):1542-9.

70) Ferris RL, Blumenschein G Jr, Fayette J, Guigay J, Colevas AD, Licitra L, et al. Nivolumab for recurrent squamous-cell carcinoma of the head and neck. N Engl J Med 2016;375(19):1856-67.

71) Harrington KJ, Ferris RL, Blumenschein G Jr, Colevas AD, Fayette $\mathrm{J}$, Licitra L, et al. Nivolumab versus standard, single-agent therapy of investigator's choice in recurrent or metastatic squamous cell carcinoma of the head and neck (CheckMate 141): Health-related quality-of-life results from a randomised, phase 3 trial. Lancet Oncol 2017;18(8):1104-15.

72) Kiyota N, Hasegawa Y, Takahashi S, Yokota T, Yen CJ, Iwae S, et al. A randomized, open-label, Phase III clinical trial of nivolumab vs. therapy of investigator's choice in recurrent squamous cell carcinoma of the head and neck: A subanalysis of Asian patients versus the global population in checkmate 141. Oral Oncol 2017;73:138-46.

73) Cavalieri S, Rivoltini L, Bergamini C, Locati LD, Licitra L, Bossi P. Immuno-oncology in head and neck squamous cell cancers: News from clinical trials, emerging predictive factors and unmet needs. Cancer Treat Rev 2018;65:78-86.

74) Bahleda R, Braiteh FS, Balmanoukian AS, Braña I, Hodi FS, Garbo L, et al. 1044OLong-term safety and clinical outcomes of atezolizumab in head and neck cancer: Phase Ia trial results. Ann Oncol 2017;28(suppl 5).

75) Zandberg DP, Algazi AP, Jimeno A, Good JS, Fayette J, Bouganim N, et al. Durvalumab for recurrent or metastatic head and neck squamous cell carcinoma: Results from a single-arm, phase II study in patients with $>25 \%$ tumor cell PD-L1 exrepssion who have progressed on platinum-based chemotherapy. Eur J Cancer 2019;107:142-52.

76) Alfieri S, Cavalieri S, Licitra L. Immunotherapy for recurrent/metastatic head and neck cancer. Curr Opin Otolaryngol Head Neck Surg 2018;26(2):152-6.

77) Larkin J, Chiarion-Sileni V, Gonzalez R, Grob JJ, Cowey CL, Lao $\mathrm{CD}$, et al. Combined nivolumab and ipilimumab or monotherapy in untreated melanoma. N Engl J Med 2015;373:23-34.

78) Aspeslagh S, Postel-Vinay S, Rusakiewicz S3 Soria JC, Zitvogel L, Marabelle A. Rationale for anti-OX40 cancer immunotherapy. Eur J Cancer 2016;52:50-66.

79) Schaer DA, Budhu S, Liu C, Bryson C, Malandro N, Cohen A, et al. GITR pathway activation abrogates tumor immune suppression through loss of regulatory T cell lineage stability. Cancer Immunol Res 2013;1(5):320-31.

80) Fisher TS, Kamperschroer C, Oliphant T, Love VA, Lira PD, Doyonnas $\mathrm{R}$, et al. Targeting of 4-1BB by monoclonal antibody PF- 05082566 enhances T-cell function and promotes anti-tumor activity. Cancer Immunol Immunother 2012;61(10):1721-33.

81) Mahoney KM, Rennert PD, Freeman GJ. Combination cancer immunotherapy and new immunomodulatory targets. Nat Rev Drug Discov 2015;14(8):561-84.

82) Chow LQM, Morishima C, Eaton KD, Baik CS, Goulart BH, Anderson LN, et al. Phase Ib trial of the toll-like receptor 8 agonist, motolimod (VTX-2337), combined with cetuximab in patients with recurrent or metastatic SCCHN. Clin Cancer Res 2017;23(10): 2442-50.

83) Massarelli E, William W, Johnson F, Kies M, Ferrarotto R, Guo M, et al. Combining immune checkpoint blockade and tumor-specific vaccine for patients with incurable human papillomavirus 16-related cancer: A phase 2 clinical trial. JAMA Oncol 2019;5(1):67-73.

84) Tan YS, Sansanaphongpricha K, Prince MEP, Sun D, Wolf GT, Lei YL. Engineering vaccines to reprogram immunity against head and neck cancer. J Dent Res 2018;97(6):627-34.

85) Yonesaka K, Zejnullahu K, Okamoto I, Satoh T, Cappuzzo F, Souglakos J, et al. Activation of ERBB2 signaling causes resistance to the EGFR-directed therapeutic antibody cetuximab. Sci Transl Med 2011;3(99):99ra86.

86) Rebucci M, Peixoto P, Dewitte A, Wattez N, De Nuncques MA, Rezvoy N, et al. Mechanisms underlying resistance to cetuximab in the HNSCC cell line: Role of AKT inhibition in bypassing this resistance. Int J Oncol 2011;38(1):189-200.

87) Topalian SL, Taube JM, Anders RA, Pardoll DM. Mechanismdriven biomarkers to guide immune checkpoint blockade in cancer therapy. Nat Rev Cancer 2016;16(5):275-87.

88) Gabrilovich DI, Nagaraj S. Myeloid-derived suppressor cells as regulators of the immune system. Nat Rev Immunol 2009;9:162-74.

89) Davis RJ, Van Waes C, Allen CT. Overcoming barriers to effective immunotherapy: MDSCs, TAMs, and Tregs as mediators of the immunosuppressive microenvironment in head and neck cancer. Oral Oncol 2016;58:59-70.

90) Park B, Yee C, Lee KM. The effect of radiation on the immune response to cancers. Int J Mol Sci 2014;15(1):927-43.

91) Uppaluri R, Zolkind P, Lin T, Nussenbaum B, Jackson RS, Rich J, et al. Neoadjuvant pembrolizumab in surgically resectable, locally advanced HPV negative head and neck squamous cell carcinoma (HNSCC). J Clin Oncol 2017;35(15 suppl):6012.

92) Ferris R, Gonçalves A, Baxi SS, Martens UM, Gauthier H, Langenberg M, et al. LBA46An open-label, multicohort, phase 1/2 study in patients with virus-associated cancers (CheckMate 358): Safety and efficacy of neoadjuvant nivolumab in squamous cell carcinoma of the head and neck (SCCHN). Ann Oncol 2017; 28(suppl 5). 
Korean J Otorhinolaryngol-Head Neck Surg I 2019;62(9):487-98

\section{정답 및 해설}

답 (4)

해 설 These lesions should be diagnosed by physical examination and imaging, and FNA should, in general, not be performed.

참고문헌: Flint PW, Haughey BH, Lund VJ, Niparko JK, Robbins KT, Thomas JR, Lesperance MM. Cummings otolaryngology head and neck surgery 6th Edition. Canada: Saunders;2015. p.1641. 